\title{
Cataract surgery: emotional reactions of patients with monocular versus binocular vision
}

\author{
Cirurgia de catarata: aspectos emocionais de \\ pacientes com visão monocular versus binocular
}

Roberta Ferrari Marback ${ }^{1}$, Rodrigo França de Espíndola ', Marcony Rodrigues de Santhiago ${ }^{2}$, Edméa Rita Temporini ${ }^{1}$, Newton Kara-Junior ${ }^{1}$

\begin{abstract}
Purpose: To analyze emotional reactions related to cataract surgery in two groups of patients (monocular vision - Group 1; binocular vision - Group 2). Methods: A transversal comparative study was performed using a structured questionnaire from a previous exploratory study before cataract surgery. Results: 206 patients were enrolled in the study, 96 individuals in Group 1 (69.3 \pm 10.4 years) and 110 in Group 2 (68.2 110.2 years). Most patients in group $1(40.6 \%)$ and $22.7 \%$ of group 2, reported fear of surgery ( $p<0.001)$. The most important causes of fear were: possibility of blindness, ocular complications and death during surgery. The most prevalent feelings among the groups were doubts about good results and nervousness. Conclusion: Patients with monocular vision reported more fear and doubts related to surgical outcomes. Thus, it is necessary that phisycians considers such emotional reactions and invest more time than usual explaining the risks and the benefits of cataract surgery.Ouvir
\end{abstract}

Keywords: Cataract extraction/psychology; Visual loss/surgery; Public health

\begin{abstract}
RESUMO
Objetivo: Verificar reações emocionais relacionadas à cirurgia de catarata entre pacientes com visão monocular (Grupo 1) e binocular (Grupo 2). Métodos: Foi realizado um estudo tranversal, comparativo por meio de um questionário estruturado respondido por pacientes antes da cirurgia de catarata. Resultados: A amostra foi composta de 96 pacientes no Grupo 1 (69.3 \pm 10.4 anos) e 110 no Grupo 2 (68.2 \pm 10.2 anos). Consideravam apresentar medo da cirugia 40.6\% do Grupo 1 e $22.7 \%$ do Grupo 2 (p<0.001) e entre as principais causas do medo, a possibilidade de perda da visão, complicações cirúrgicas e a morte durante o procedimento foram apontadas. Os sentimentos mais comuns entre os dois grupos foram dúvidas a cerca dos resultados da cirurgia e o nervosismo diante do procedimento. Conclusão: Pacientes com visão monocular apresentaram mais medo e dúvidas relacionadas à cirurgia de catarata comparados com aqueles com visão binocular. Portanto, é necessário que os médicos considerem estas reações emocionais e invistam mais tempo para esclarecer os riscos e benefícios da cirurgia de catarata.

Descritores: Extração de catarata/psicologia; Cegueira/cirurgia; Saúde Pública
\end{abstract}

\footnotetext{
${ }^{1}$ Ophthalmology Department, Universidade de São Paulo (USP) - São Paulo (SP), Brazil;

${ }^{2}$ Cole Eye Institute, Cleveland Clinic Foundation, Cleveland, USA.

The study was carried out at the Ophthalmology Department, Universidade de São Paulo - USP - São Paulo (SP), Brazil.
}

The authors declare no conflicts of interest

Recebido para publicação em: 30/11/2011 - Aceito para publicação em: 12/3/2012

Rev Bras Oftalmol. 2012; 71 (6): 385-9 


\section{INTRODUCTION}

$\mathbf{T}$ he illness is felt by the patient as a break in the course of life, inadequate, unwanted phenomenon that affects and is able to modify the whole routine. There are different ways to react to disease and its treatment. Subjective personal meaning which arouses the disease is of fundamental importance, depending on the personality characteristics, social circumstances and characterization of disease and its treatment. ${ }^{(1)}$

Usually, the illness is experienced as an unexpected situation for which the individuals are not well prepared, once they do not choose to be ill. With surgery, the situation is not different, it becomes something new and unknown which can lead to high levels of anxiety and waking fantasies. ${ }^{(2,3)}$

The need for surgery as a factor potentially stressful and tends to cause physiological responses in patients (elevation of pulse, increase of blood pressure levels), cognitive (beliefs about negative consequences and inability to concentrate), emotional (anxiety and depression) and behavioral. The moment of receiving surgery news can then be experienced in different ways. ${ }^{(4)}$

With scientific advances, the continuing improvement of surgical techniques have made cataract surgery an outpatient procedure with local anesthesia and a growing safer and more efficient procedure. ${ }^{(5)}$ Phacoemulsification is an efficient procedure in Brazil with regard to its impact on the public health care system. ${ }^{(6)}$ However, despite the subsequent success to the improvement of surgical techniques, patients tend to have high levels of fear and anxiety in the preoperative period. . $^{(4,7)}$

During cataract surgery, patients are awake and need to collaborate with the surgeon, keeping silent, motionless, keeping the eye in the same position. If their emotional reactions are not considered, there may not be cooperative with possible injury to surgery..$^{(9)}$

The aim of this study was to analyze emotional reactions in two groups of patients, with monocular vision and binocular vision before they submit to cataract surgery.

\section{Methods}

A transversal comparative study was performed compromising patients with monocular and binocular vision to be submitted to cataract surgery in a public hospital in São Paulo. Two groups were formed for comparison in a non-probabilistic sample: Group 1 - individuals with monocular vision; Group 2 individuals with binocular vision, to be submitted to cataract surgery for the first time in the worst eye vision. All patients enrolled had no previous cataract surgery.

It was considered that the individual who had monocular vision was diagnosed with irreversible blindness in one eye visual acuity less than or equal to $0.10(20 / 200)$ by the Snellen chart or visual field less than 20 degrees. ${ }^{(10)}$ In patients with binocular vision, it was considered that both eyes had potential vision with possibility of significant improvement in visual acuity after cataract surgery.

Given the diversity of social and cultural characteristics, we chose to lead the study through a questionnaire prepared from exploratory research among patients with similar characteristics to the sample. ${ }^{(11-14)}$ Data collection was carried out from march 2006 to march 2007.

Before starting the interviews, patients were explained about the goals and methods of the research and assured anonymity and confidentiality of information provided by them, besides the absence of risks regarding the treatment offered at the hospital. The study was conducted in adherence with the tenets of the Declaration of Helsinki and approval of the study was obtained from the institutional review board of Clinical Hospital, São Paulo, Brazil. All patients received a detailed explanation of the study and provided written informed consent.

Statistical analysis was performed using SPSS for Windows (version 115; SPSS, Inc, Chicago, Illinois, USA). For primary outcome measures, the statistical tests were conducted at a level of 0.05. The Chi-square and Fisher's exact test was used.

\section{ResULTS}

A total of 206 patients were enrolled in the study. The Group 1 comprised 96 subjects (50.0\% female), mean age of 69.3 \pm 10.4 years. The other group consisted of 110 subjects $(59.1 \%$ female), mean age $68.2 \pm 10.2$ years. There was no statistically difference between both groups among gender $(\mathrm{p}=0.191)$, age $(\mathrm{p}=0.702)$ and education level $(\mathrm{p}=0.245)($ Table 1$)$.

Regarding the fears about surgery, $59.4 \%$ of patients in Group 1 reported not to be afraid, $25.0 \%$, very afraid and $15.6 \%$ showed a little fear. From those that had fear of surgery, the predominated responses were: fear of blindness $(94.9 \%)$, worsening of vision $(92.3 \%)$, complications in the surgery $(87.2 \%)$, fear of the anesthesia $(61.5 \%)$, pain during surgery $(56.4 \%)$, death during surgery $(51.3 \%)$ and pain in the postoperative period $(51.3 \%)$.

Table 1

Personal characteristics of patients with monocular vision (Group 1) and binocular vision (Group 2) undergoing cataract surgery

\begin{tabular}{|c|c|c|c|c|c|}
\hline \multirow{2}{*}{ Characteristics } & \multicolumn{2}{|c|}{ Group 1} & \multicolumn{2}{|c|}{ Group 2} & \multirow{2}{*}{$\mathbf{p}^{1}$} \\
\hline & $\mathrm{n}$ & $\%$ & $\mathrm{n}$ & $\%$ & \\
\hline & \multicolumn{2}{|c|}{$\mathrm{n}=96$} & \multicolumn{2}{|c|}{$\mathrm{n}=110$} & \\
\hline \multicolumn{6}{|l|}{ Gender } \\
\hline Male & $4 \varepsilon$ & 50.0 & 45 & 40.9 & \\
\hline \multirow[t]{2}{*}{ Female } & 48 & 50.0 & 65 & 59.1 & 0.191 \\
\hline & \multicolumn{2}{|c|}{$\mathrm{n}=39$} & \multicolumn{2}{|c|}{$\mathrm{n}=25$} & \\
\hline \multicolumn{6}{|l|}{ Age (years) } \\
\hline $40-60$ & 17 & 17.7 & 18 & 16.4 & \\
\hline $60-70$ & 28 & 29.2 & 32 & 29.1 & \\
\hline $70-80$ & 35 & 36.4 & 47 & 42.7 & \\
\hline $80-91$ & 16 & 16.7 & 13 & 11.8 & 0.702 \\
\hline $\mathrm{X}^{2} \pm \mathrm{SD}^{3}$ & \multicolumn{2}{|c|}{$69.3 \pm 10.4$} & \multicolumn{2}{|c|}{$68.2 \pm 10.2$} & \\
\hline \multicolumn{6}{|l|}{ Education level } \\
\hline \multicolumn{6}{|l|}{ Never atendded } \\
\hline \multicolumn{6}{|c|}{ Primary School } \\
\hline - incomplete & 59 & 61.5 & 74 & 67.3 & \\
\hline · complete & 2 & 2.1 & 8 & 7.3 & \\
\hline \multicolumn{6}{|l|}{ Secondary School } \\
\hline - incomplete & 1 & 1.0 & 2 & 2.8 & \\
\hline - complete & 6 & 6.2 & 7 & 6.4 & \\
\hline \multicolumn{6}{|l|}{ College } \\
\hline - incomplete & 2 & 2.1 & - & - & \\
\hline - complete & 4 & 4.2 & 3 & 2.7 & 0.245 \\
\hline
\end{tabular}

${ }^{1}$ Chi-square test $;{ }^{2}$ average $;{ }^{3}$ standard deviation 
In Group 2, 77.3\% showed no fear of surgery, $10.0 \%$ were very afraid and $12.7 \%$ showed a little fear. From those that had fear of surgery, the predominant responses were: fear of blindness $(84.0 \%)$; worsening of vision $(84.0 \%)$; complications in the surgery $(84.0 \%)$; fear of the anesthesia $(76.0 \%)$; pain during surgery $(48.0 \%)$ and in the postoperative period $(48.0 \%)$. There was statistically significant difference between groups $(\mathrm{p}=0.009)$ considering the degree of fear (Table 2).

Considering feelings expressed due cataract surgery, $96.9 \%$ in Group 1 mentioned pleased to know that surgery could improve their vision, $95.8 \%$, showed relief to know that they were going to surgery, $50.0 \%$ had doubts about surgery outcomes, $43.8 \%$ showed nervousness, $40.6 \%$ restlessness and $36.5 \%$ doubts about the surgery.

All patients in Group 2 expressed satisfaction that cataracts can be operated and improved vision and relief to know that they will perform the surgery, $32.7 \%$ revealed nervousness, $30.0 \%$ showed doubts about surgery outcomes. There was a statistically difference between groups in the categories of relief knowing that they will undergo surgery $(\mathrm{p}=0.046)$, doubts about having good surgical result $(p=0.003)$, restlessness $(p=0.001)$, discomfort $(p=0.002)$, feeling of strangeness $(p=0.010)$, trust in God for vision improvement $(\mathrm{p}=0.001)$, hope $(\mathrm{p}=0.001)$, happiness $(\mathrm{p}=0.024)$ and worry $(\mathrm{p}=0.016)($ Table 3$)$.

\section{Discussion}

Regarding personal characteristics, it was observed that there was no statistically difference between groups regarding gender $(\mathrm{p}=0.191)$, age $(\mathrm{p}=0.702)$ and education level $(\mathrm{p}=$

Table 2

Opinion concerning degree and cause of fear of patients with monocular vision (Group 1) and binocular vision (Group 2) undergoing cataract surgery

\begin{tabular}{|c|c|c|c|c|c|}
\hline \multirow{2}{*}{ Opinion } & \multicolumn{2}{|c|}{ Group 1} & \multicolumn{2}{|c|}{ Group 2} & \multirow{2}{*}{$\mathbf{p}$} \\
\hline & $\mathrm{n}$ & $\%$ & $\mathrm{n}$ & $\%$ & \\
\hline & \multicolumn{2}{|c|}{$\mathrm{n}=96$} & \multicolumn{2}{|c|}{$\mathrm{n}=110$} & \\
\hline \multicolumn{6}{|l|}{ Degree of fear } \\
\hline Very afraid & 24 & 25.0 & 11 & 10.0 & \\
\hline Little fear & 15 & 15.6 & 14 & 12.7 & \\
\hline Not afraid & 57 & 59.4 & 85 & 77.3 & $0,009^{2}$ \\
\hline & \multicolumn{2}{|c|}{$\mathrm{n}=39$} & \multicolumn{2}{|c|}{$\mathrm{n}=25$} & \\
\hline
\end{tabular}

\begin{tabular}{lccccc}
\hline \begin{tabular}{l} 
Reason \\
\multicolumn{1}{l}{$\begin{array}{l}\text { Possibility of } \\
\text { loss of vision }\end{array}$}
\end{tabular} & 37 & 94.9 & 21 & 84.0 & $0.199^{3}$ \\
$\begin{array}{l}\text { Worsening of vision } \\
\text { Complications during }\end{array}$ & 36 & 92.3 & 21 & 84.0 & $0.417^{3}$ \\
$\begin{array}{l}\text { surgical procedure } \\
\text { Anesthesia }\end{array}$ & 34 & 87.2 & 21 & 84.0 & $0.728^{3}$ \\
Pain in surgery & 24 & 61.5 & 19 & 76.0 & $0.229^{2}$ \\
Pain postoperatively & 20 & 56.4 & 12 & 48.0 & $0.511^{2}$ \\
Die during surgery & 20 & 51.3 & 12 & 48.0 & $0.798^{2}$ \\
Known permormed & & & 3 & 12.0 & $0.001^{2}$ \\
surgery and worsened & 5 & 12.8 & 1 & 4.0 & $0.391^{3}$ \\
Religious principles & 2 & 5.1 & - & - & $0.516^{3}$ \\
Another & 1 & 2.6 & - & - & $1.000^{3}$ \\
\hline
\end{tabular}

\footnotetext{
${ }^{1}$ Afirmative and multiple responses; ${ }^{2}$ Chi-square test; ${ }^{3}$ Fisher's exact test
}

Table 3

Feelings expressed by patients with monocular vision (group 1) and binocular vision (group 2) undergoing cataract surgery. (Affirmative and multiple responses)

\begin{tabular}{|c|c|c|c|c|c|}
\hline & $\mathbf{G}$ & & & & \\
\hline \multirow{2}{*}{ Feeling } & & $\%$ & $\mathrm{n}$ & $\%$ & \multirow[b]{2}{*}{$\mathbf{p}$} \\
\hline & \multicolumn{2}{|c|}{$\mathrm{n}=96$} & \multicolumn{2}{|c|}{$\mathrm{n}=110$} & \\
\hline
\end{tabular}

Satisfaction knowing

that a cataract can be

operated and improve-

$\begin{array}{llllll}\text { ment of vision } & 93 & 96.9 & 110 & 100.0 & 0.100^{1}\end{array}$

Relief knowing that

will be submitted to

$\begin{array}{llllll}\text { surgery } & 92 & 95.8 & 110 & 100.0 & 0.046^{1}\end{array}$

$\begin{array}{lllllll}\text { Doubt about good result } & 48 & 50.0 & 33 & 30.0 & 0.003^{2}\end{array}$

$\begin{array}{llllll}\text { Nervousness } & 42 & 43.8 & 36 & 32.7 & 0.104^{2}\end{array}$

$\begin{array}{llllll}\text { Restnessless } & 39 & 40.6 & 15 & 13.6 & 0.001^{2}\end{array}$

$\begin{array}{llllll}\text { Doubt about the surgery } & 35 & 36.5 & 30 & 27.3 & 0.157^{2}\end{array}$

$\begin{array}{llllll}\text { Discomfort } & 31 & 32.3 & 16 & 14.5 & 0.002^{2}\end{array}$

$\begin{array}{llllll}\text { Feeling of strangeness } & 27 & 28.1 & 15 & 13.6 & 0.010^{2}\end{array}$

Trust in God for vision

$\begin{array}{llllll}\text { improvement } & 26 & 27.1 & 6 & 5.4 & 0001^{2}\end{array}$

Sadness in having to

operate

Irritability

Chest tightness

Anxiety

Hope

Hapiness

Worry

Anothers ${ }^{3}$

Anger for having

to operate

$25 \quad 26.0$

23.9

22.9

21,9

$11 \quad 11.5$

$10 \quad 10.4$

$9 \quad 9.4$

$4 \quad 4.2$

$\begin{array}{lll}18 & 16.4 & 0.088^{2}\end{array}$

$19 \quad 17,3 \quad 0.235^{2}$

$15 \quad 13,6 \quad 0.083^{2}$

$\begin{array}{lll}14 & 12.7 & 0.081^{2}\end{array}$

$\begin{array}{lll}- & - & 0.001^{2}\end{array}$

$\begin{array}{lll}3 & 2.7 & 0.024^{2}\end{array}$

$\begin{array}{lll}3 & 1.8 & 0.016^{2}\end{array}$

$3.1-2-1.8-0.666$

${ }^{1}$ Fisher's exact test; ${ }^{2}$ Chi-square test $;{ }^{3}$ other feelings expresses firmness, loss of appetite, chills and fatigue

Table 4

Feeling of doubt as to have good results in surgical patients with monocular vision (group 1) compared with patients with binocular vision (group 2) undergoing cataract surgery

\begin{tabular}{ccccccc}
\hline & \multicolumn{3}{c}{ Doubt in having good results in surgery? } \\
\hline \multirow{2}{*}{ Group } & \multicolumn{2}{c}{ Yes } & \multicolumn{2}{c}{ No } & \multicolumn{2}{c}{ Total } \\
\cline { 2 - 7 } & $\mathrm{N}$ & $\%$ & $\mathrm{n}$ & $\%$ & $\mathrm{n}$ & $\%$ \\
\hline 1 & 48 & 50.0 & 48 & 50.0 & 96 & 100.0 \\
2 & 33 & 30.0 & 77 & 70.0 & 110 & 100.0 \\
\hline
\end{tabular}

0.245) (Table 1). The educational level was low in both groups: $84.4 \%$ and $81.8 \%$ of respondents in Groups 1 and 2, respectively, did not study or had incomplete primary educational background. These data are typical of poor people attended at public hospital in a developing country such as Brazil. ${ }^{(15)}$ Studies with similar population carried out in developed countries such as United States, showed highest level of education in which $29 \%$ of subjects had finished college. ${ }^{(16)}$ In this study, only $4.2 \%$ and $2.7 \%$ of respondents in Groups 1 and 2, respectively, had finished college (Table 1). 
A significant proportion of patients in Group 1 (25.0\%) reported "very afraid of surgery" and $10.0 \%$ in Group 2 delivered the same answer, $59.4 \%$ and $77.3 \%$ in Groups 1 and 2 respectively, did not mention fear and the difference between the groups was statistically significant $(p=0.009)$. The requirement of having indication for cataract surgery by itself is cited in several studies as a important cause of fear..$^{(4,15-17)} \mathrm{A}$ study performed in Campinas (Brazil) and Chimbote (Peru) noted that $30.0 \%$ of individuals diagnosed with cataract refused surgery because of fear. ${ }^{(18)}$

When analyzing the main causes of fear, it was observed that among the sensations of blindeness, worsening of vision, surgery complications, fear of anesthesia, pain, religious principles, there was no statistically significant difference between groups, suggesting that even individuals with binocular vision are afraid of losing or getting worse. The difference between groups regarding fear of death during surgery was statistically significant, being mentioned in $51.3 \%$ of subjects in Group 1 (Table 2). It is believed that patients with monocular vision are more afraid of surgery compared to those with binocular vision, but they may be unable to precisely the cause of this fear. ${ }^{(18)}$

Death as a cause of fear in cataract surgery among Brazilian patients has been reported in previous studies. ${ }^{(15,17,19,20)}$ Fear related to anesthesia has been reported by several studies in several kinds of surgery. ${ }^{(3,21-23)}$ In cataract surgery data were found that the most stressful facts for patients undergo surgery is the anesthesia than the surgery itself. ${ }^{(4)}$

Research carried out with individuals undergoing cataract surgery reported that $40.8 \%$ of patients showed fear of pain during surgery. ${ }^{(17)}$

Fear of the unknown becomes the main cause of insecurity and anxiety of patients before surgery. Other study shows that fear of death during anesthesia, the procedure itself and the recovery period were the most prevalent ones. ${ }^{(3)}$

A study of visual experiences during phacoemulsification with topical anesthesia showed that preoperative counseling was responsible for the reduction of fear reported by patients and that factors which was relationaded to the experience of fear was young patients, female and being undergoing cataract surgery for the first time.(24)

Consedering the feelings expressed by interviewees related to surgery when the cataract was identified as a cause of visual impairment, it was observed that majority of respondents in both groups reported satisfaction by knowing that cataracts can be operated and improved their vision. These data suggest the high expectations regarding the improvement of vision (Table 3).

Individuals with monocular vision (Group 1) mentioned in a great extent some feelings: hope, happiness, doubt about surgical outcomes, restlessness, discomfort, feelings of strangeness, trust in God for improving vision and concern, with statistically significant difference between groups (Table 3).

It is observed that many individuals tend to cling to religion, probably in attempt to gain control over the situation that they are experiencing. The respondents in Group 1, probably by the condition of having monocular vision, were more confident in God.

Research with pre-surgical patients of hysterectomy, cholecystectomy and varicose veins showed that individuals rely on religion in order to cope. ${ }^{(3)}$ A study in an ophthalmic emergency room found that given the eye problem, one of the first actions of the patients was praying to God, identifying the strong religiosity of them. ${ }^{(25)}$ The feelings of hope and happiness were mentioned by $11.5 \%$ and $10.4 \%$ of subjects in Groups 1 and 2, respectively. Among Group 2, there was no reference of interviewees related to hope and only $2.7 \%$ indicated happiness, data that may be related to increased need for visual rehabilitation of individuals in Group 1 compared with the other Group (Table 3).

Consedering the feeling of doubt about surgical outcomes, it was observed the predominance of negative responses in Group 1 with a statistically significant difference $(p=0.003)$. These results may suggest that individuals in Group 1 shows least confidence in the success of the procedure and have postponed the search for the surgery. The adverse situation of having already lost a vision and experience of this loss, perhaps, makes the individuals of Group 1 imagine losing sight of the other eye, while the ones in Group 2, who have not had the same experience, cannot imagine themselves in that situation, being more optimistic about the surgery outcomes.OuviLer foneticamente

\section{Conclusion}

This study suggests that patients with monocular vision tend to be more afraid of cataract surgery than binoculars individuals. Thus, it is necessary that phisycians considers such emotional reactions and invest more time than usual explaining the risks and the benefits of cataract surgery.

\section{ACKNOWLEDGEMENT}

This research was supported by a grant from "Coordenação de Aperfeiçoamento de Pessoal de Nível Superior (CAPES - MEC)", Brasília, Brazil. The authors have no proprietary or commercial interest in any materials discussed in this article.

\section{REFERENCES}

1. Botega NJ. Reação à doença e à hospitalização. In: Botega NJ, organizador. Prática psiquiátrica no hospital geral: interconsulta e emergência. Porto Alegre: Artmed Editora; 2002. p. 43-59.

2. Roth MC. Atendimento psicológico domiciliar. In: AngeramiCamon VA. Novos rumos na psicologia da saúde. São Paulo: Pioneira Thomson Learning; 2002. p. 125-72.

3. Fighera J, Viero EV. Vivências do paciente com relação ao procedimento cirúrgico: fantasias e sentimentos mais presentes. Rev SBPH. 2005;8(2):51-63.

4. Nijkamp MD, Ruiter RA, Roeling M, van der Borne B, Hiddema F, Hendrikse F, Nuijts RM. Factors related to fear in patients undergoig cataract surgery: a qualitative study focusing on factors associated with fear and reassurance among patients who need to undergo cataract surgery. Patient Educ Couns. 2002;47 (3):265-72.

5. Fine IH, Packer M, Hoffman RS. New phacoemulsification technologies. J Cataract Refract Surg. 2002;28(6):1054-60.

6. Kara-Jr N, Sirtoli MG, Santhiago MR, Parede TR, Espíndola RF, Carvalho Rde S. Phacoemulsification versus extracapsular extraction: governmental costs. Clinics (Sao Paulo). 2010;65(4):357-61.

7. Foggitt PS. Anxiety in cataract surgery: pilot study. J Cataract Refract Surg. 2001;27(10):1651-5.

8. Nijkamp MD, Kenens CA, Dijker AJ, Ruiter RA, Hiddema F, Nuijts RM. Determinants of surgery related anxiety in cataract patients. Br J Ophthalmol. 2004;88(10):1310-4.

9. Morrell G. Effect of structured preoperative teaching on anxiety levels of patients scheduled for cataract surgery. Insight. 2001;26(1):4-9.

10. International Council of Ophthalmology. Visual Standards: Aspects and Ranges of Vision Loss with Emphasis on Population Surveys. 29 $9^{\text {th }}$ International Congress of Ophtalmology. Sydney, Austrália; April 2002. 
11. Piovesan A, Temporini ER. Pesquisa exploratória: procedimento metodológico para o estudo de fatores humanos no campo da saúde pública. Rev Saúde Pública. 1995;29(4):318-25.

12. Kara-Júnior N, Temporini ER, Kara-José N. Cataract surgery: expectations of patients assisted during a community project in São Paulo, state of São Paulo, Brazil. Rev Hosp Clin Fac Med Sao Paulo. 2001;56(6):163-8.

13. Temporini ER, Kara Júnior N, José NK, Holzchuh N. Popular beliefs regarding the treatment of senile cataract. Rev Saúde Pública. 2002;36(3):343-9.

14. Temporini ER, Kara-José N. A perda da visão: estratégias de prevenção. Arq Bras Oftalmol. 2004;67(4):597-601.

15. Temporini ER, José NK, José Júnior NK. Catarata senil: características e percepções de pacientes atendidos em projeto comunitário de reabilitação visual. Arq Bras Oftalmol. 1997;60(1):79-83.

16. Steinberg EP, Tielsch JM, Schein OD, Javitt JC, Sharkey P, Cassard $\mathrm{SD}$, et al. National study of cataract surgery outcomes. Variation in 4-month postoperative outcomes as reflected in multiple outcome measures. Ophthalmology. 1994;101(6):1131-40; discussion 1140-1.

17. Oliveira Rde S, Temporini ER, Kara José N, Carricondo PC, Kara José AC. Perceptions of patients about cataract. Clinics (Sao Paulo). 2005;60(6):455-60.

18. José NK, Contreras F, Campos MA, Delgado AM, Mowery RL Ellwein LB. Screening and surgical intervention results from cataract-free-zone projects in Campinas, Brazil and Chimbote, Peru. Int Ophthalmol. 1990;14(3):155-64.

19. Marback R, Temporini E, Kara Júnior N. Emotional factors prior to cataract surgery. Clinics (Sao Paulo). 2007;62(4):433-8.
20. Marback RF. Cirurgia de catarata: opiniões, expectativas e reações emocionais de pacientes com visão mono versus binocular [tese]. São Paulo: Faculdade de Medicina da Universidade de São Paulo; 2007.

21. Brown SM. Quantitative measurement of anxiety in patients undergoing surgery for renal calculus disease. J Adv Nurs. 1990;15(8):962-70.

22. Oliveira MFP, Luz PL.O impacto da cirurgia cardíaca. In: Mello Filho J. Psicossomática hoje. Porto Alegre: Artes Médicas; 1992. p. 253-8.

23. Moraes LO, Peniche ACG. Ansiedade e mecanismos de coping utilizados por pacientes cirúrgicos ambulatoriais. Rev Esc Enferm USP. 2003;37(3):54-62.

24. Voon LW, Au Eong KG, Saw SM, Verma D, Laude A. Effect of preoperative counseling on patient fear from the visual experience during phacoemulsification under topical anesthesia: Multicenter randomized clinical trial. J Cataract Refract Surg. 2005;31(10):1966-9.

25. Carvalho RS. Conduta leiga e assistência médica em pacientes do Pronto-Socorro de Oftalmologia do Hospital das Clínicas da Faculdade de Medicina da Universidade de São Paulo [tese]. São Paulo: Faculdade de Medicina da Universidade de São Paulo; 2007.

\section{Autor correspondente:}

Rodrigo França de Espíndola

Praça das Hortências, $\mathrm{n}^{\circ} 70$ Cond. Portal de ltu

Zip Code: 13301-689 - Itu (SP), Brasil

E-mail: rodrigo166@uol.com.br 